\title{
Food insecurity in families with children under five years of age on the Brazil-Peru Amazon border
}

\author{
Alanderson Alves Ramalho' ${ }^{1}$, Saulo Augusto Silva Mantovani ${ }^{1}$, Humberto Oliart-Guzmán ${ }^{1}$, \\ Fernando Luiz Cunha Castelo Branco ${ }^{1}$, Athos Muniz Braña ${ }^{1}$, Antonio Camargo Martins ${ }^{1}$, \\ Thasciany Moraes Pereira ${ }^{1}$, Breno Matos Delfino ${ }^{1}$, José Alcântara Filgueira Júnior ${ }^{1}$, \\ Carlos Hermogenes Manrique de Lara Estrada ${ }^{2}$, Nancy Arrospide Velasco ${ }^{3}$, Monica da Silva-Nunes ${ }^{1}$
}

DOI: http://dx.doi.org/10.7322/jhgd.122761

\begin{abstract}
:
Food and nutrition security is the regular and permanent access to quality food in sufficient quantity. The aim of this study was to estimate the prevalence and factors associated with food insecurity in households with children under five in the Amazon frontier Brazil - Peru. The study was conducted in 352 households in Assis Brasil (Brazil) and 89 households Iñapari (Peru), finding a prevalence of food insecurity of $40.6 \%$ and $38.2 \%$, respectively $(p=0.856)$. In Assis Brasil, having domicile with wood floors or land increased by 2.47 times the odds of food insecurity compared to cement floors, ceramic or quarry tiles. Belonging to the poorest tertile increased the chance of food insecurity in 6.04 times $(p<$ 0.001 ), and the increment of each new resident increased by $37 \%$ the chance of food insecurity in the household . In Iñapari, only living in house made of wood or with a wood floor was associated with food insecurity, showing that income is still the main factor associated with food insecurity in the Amazonian borders.
\end{abstract}

Keywords: food security, border health, hunger.

\section{INTRODUCTION}

Food and nutritional security consists in ensuring the right for all to regular and permanent access to quality food in sufficient amounts without compromising access to other essential needs, based on dietary practices that can promote health and respect cultural diversity and that are environmentally, culturally, economically and socially sustainable ${ }^{1}$.

The major international measure to achieve food security is based on the first of the Millennium Development Goals (Eradicate extreme poverty and hunger) ${ }^{2}$, concomitantly with the human right to a proper diet. It is estimated that 1 billion people worldwide do not have access to sufficient food in order to meet basic nutritional requirements or live in a condition of continual hunger, which indicates moderate and severe food insecurity ${ }^{3}$.

The National Survey by Household Sampling (Pesquisa Nacional por Amostragem de Domicílios $P N A D$ ), conducted in 2009, estimated that the prevalence of food insecurity in urban areas in Brazil was 30.9\% and that severe food insecurity was $5.0 \%$. The largest preva- lence rates were found in the Northeastern $(46.1 \%)$ and Northern (40.3\%) Regions. In Acre, $47.5 \%$ of the families residing in urban areas lived in food insecurity, and 10.4\% were found to be in a severe condition ${ }^{4}$.

Food insecurity is mainly determined by poverty and social inequality 5 . Studies that analyze factors associated with food insecurity are decisive for designing programs and public policies of preventive character and for health promotion'.

The outcomes of food insecurity can be observed mainly in the most vulnerable groups. Child mortality, impaired physical and mental development, low weight at birth, maternal mortality, increased school dropout and poorer school performance are events related to the lack of a healthy quality diet as a consequence of precarious access to income and to goods and services ${ }^{7}$. For instance, low birth at weight is still a common feature in $\mathrm{Acre}^{8}$, while low weight for height in school children is not frequent ${ }^{9}$. This could be a consequence of maternal exposition to food insecurity during pregnancy, which is modified later by food received at school. Various international studies have reported a direct relationship

\footnotetext{
1 Universidade Federal do Acre.

2 Dirección Regional de Salud de Madre de Dios.

3 Instituto Nacional de Salud, Perú.

Corresponding author: Monica da Silva-Nunes. E-mail: msnunes1@yahoo.com.br
}

Suggested citation: Ramalho AA, Mantovani SAS, Oliart-Guzmán H, Branco FLCC, Braña AM, Martins AC, et al. Food insecurity in families with children under five years of age on the Brazil-Peru Amazon border. J Hum Growth Dev. 2016 ; 26 (3): $307-315$. Doi: http://dx.doi.org/10.7322 gd.119236

Manuscript submitted 27 Feb. 2015, accepted for publication 8 Oct. 2016. 
of food insecurity with an impaired nutritional status in children $^{10-13}$, and nutritional deficits are still a common feature in Brazilian children less than five years old ${ }^{14}$, suggesting a high prevalence of food insecurity in some areas of the country.

Although some studies have been performed on food insecurity in the general population in the Amazon $^{15,16}$, there are no specific publications addressing the situation of children in that region. The Amazon has a large diversity of fish and fruit, which should represent an abundant supply of energy, protein, vitamins and minerals, thus providing excellent health, nutrition and life-quality standards to its different population groups ${ }^{17}$. However, the social and economic reality added to the precarious health and nutritional conditions reported in that region strongly contrast with its richness of biological resources. ${ }^{17}$ This study aimed at estimating the prevalence of and the factors associated with food insecurity in families with children under five years of age on the Brazil-Peru Amazon border.

\section{METHODS}

The study was conducted in the cities of Assis Brasil (Brazil) and Iñapari (Peru), located on the triple border formed by Brazil, Bolivia and Peru. Assis Brasil is located on the Acre River Valley (Vale do Rio Acre), 344 miles to the Southwest of Rio Branco, the capital city of Acre state. It covers an area of $4,974 \mathrm{~km}^{2}$, and it is bordered by the city of Brasiléia, to the East, and by the cities of Bolpebra (Bolivia) and Iñapari (Peru), to the South. In 2010, Assis Brasil had a total population of (urban and rural areas) of 6,017 inhabitants (3,057 men and 2,960 women) of whom $12.76 \%$ were 0 to 4 years old ${ }^{18}$.

The city of Iñapari, with $21,126 \mathrm{~km}^{2}$, is located in the department of Madre de Dios, in the Amazon province of Tahuamanu. It is limited by the Acre River, on the border with Brazil, and the Yaverija River, on the border with Bolivia, thus being $241 \mathrm{~km}$ away from Puerto Maldonado. In 2007, its population comprised 996 individuals $^{19}$, and the population forecast for 2010 was of 1,434 people ${ }^{20}$.

The population studied was selected from the census of households showing at least one child under 5 years of age, residing in the urban areas in the cities of Assis Brasil and Iñapari. Such households were found by using the Health Care Units of both cities.

Data were collected from January to February 2011 by means of interviews using questionnaires in order to investigate the children's socioeconomic, environmental and parental characteristics as well as their nutritional status.

Data concerning the family and family head's income were collected. However, that information was inadequate for analysis due to various reasons (inconsistent income due to temporary jobs, refusal to inform about income or lack of knowledge about the income of all family members or about income in the form of goods instead of money). Therefore, the researchers opted for designing a wealth index for the families, as those vali- dated by Filmer and Pritchett for urban areas ${ }^{21}$, which was described in detail in a previous study ${ }^{22}$.

Digital pediatric scales (Soehnle ${ }^{\circledR}$ ) with 10 -g precision and 16-kg maximum capacity were used to measure the body weight of children under 2 years of age. A portable digital scale (Plenna $\AA$ ) with 100 -g precision and $150-\mathrm{kg}$ maximum capacity was used for children over two years of age. The children's length was obtained by using a portable infantometer with $1-\mathrm{cm}$ precision placed on a flat surface. The height of children over 2 years of age was measured by a wooden stadiometer with $0.1-\mathrm{cm}$ precision mounted on a wall without baseboards at a $90^{\circ}$ degree angle in relation to the floor. All the anthropometric measurements were taken in duplicates. Whenever the two measurements differed, a third one was taken, and the two closest measurements were selected.

The Brazilian Food Insecurity Scale (Escala Brasileira de Insegurança Alimentar - EBIA) was adopted to measure the magnitude of family food insecurity. It was obtained by means of a structured questionnaire whose questions followed an increasing order of severity, beginning with those related to the concern about the possibility of lack of food, addressing the reduction in food quality and quantity in the family and finalizing with specific questions about the lack of food for one or more days ${ }^{23}$. Studies in Peru usually use the Latin American and Caribbean Food Security Scale (ELCSA). ELCSA was based on EBIA, and they are both very similar ${ }^{24}$. Since the objective was to compare both cities EBIA was used in both countries.

\section{Statistical analysis}

The socioeconomic index was obtained by Principal Component Analysis (PCA), using software XLSTAT, version 7.5.2 (Addinsoft, New York, NY, covariance parameters $(\mathrm{n}-1)$ and correlation biplot / coefficient $=n$, as described by Filmer and Pritchet ${ }^{21}$. Such index was created based on the presence of twenty-one consumer goods and house appliances (television, music system, DVD player, gas stove, refrigerator, washing machine, telephone, bicycle, blender, electric iron, car, sofa, satellite dish, cellular telephone, motorcycle, computer, boat, motor boat, water well, power generator and microwave oven), as described in a previous publication $^{22}$.

Height deficit was identified by the index height for age by adopting the cutoff point for height deficit for age $\leq-2$ scores $Z^{25}$.

In order to analyze the food insecurity questionnaire, each affirmative answer represented 1 point, and the sum of such affirmative answers was the scale score, which ranged in the amplitude of 0 to 15 points. The families obtaining 0 points were considered to be in food security; slight insecurity from 1 to 5 points; moderate insecurity from 6 to 10 points and severe insecurity from 11 to 15 points.

A database was created in software SPSS 13.0 (SPSS Inc., Chicago, IL). The distribution of independent variables was identified by using the KolmogorovSmirnov test. Software R 2.14.0 was used for simple logistic regression analysis by analyzing the associated 
factors and potential confusion factors, including categorical and continuous variables.

Initially, the independent variables showing associations with food insecurity with a $p$ value $<0.20$ (chi-square test for heterogeneity and of linear tendency) were selected to enter the final multiple model. In a second phase, multiple logistic regression was performed according to the stepwise forward method, and all the variables showing a $p$ value $<0.05$ were retained in the final model. The quality of fitting of the model was evaluated by the variance value, AIC (Akaike's Information Criterion) values.

The study was approved by the Ethics Committee for Human Research of Acre Federal University (Brazil) and of Instituto Nacional de Salud (Lima, Peru), processes 23107.008153/2010-92 UFAC and 2010-CI-59 - INS). Informed consent was obtained from the participants in the study or from the parents or legal guardians of the minors prior to the interview.

\section{RESULT}

Of the 441 households with children under 5 years of age identified, 352 (79.82\%) were located in Assis Brasil, and the others in Iñapari.

Table 1 shows the comparison of the socioeconomic and demographic characteristics between the families in Assis Brasil (AB) and Iñapari (IN). In both cities, the houses are predominantly made of wood or similar materials, with wooden or earthen floors. The majority of streets are unpaved; however, in Iñapari, there are more sidewalks (47.2\%) than in Assis Brasil (24.4\%, $\mathrm{p}<0.001)$.

Table 1: Socioeconomic, demographic and nutritional characteristics. Assis Brasil; Iñapari, 2011

\begin{tabular}{|c|c|c|c|c|c|}
\hline \multirow[b]{2}{*}{ Variables } & \multicolumn{2}{|c|}{$\begin{array}{l}\text { Assis Brasil } \\
(n=352)\end{array}$} & \multicolumn{2}{|c|}{$\begin{array}{l}\text { I ñapari } \\
(\mathbf{n}=89)\end{array}$} & \multirow[b]{2}{*}{ p-value } \\
\hline & $\mathbf{N}$ & $\%$ & $\mathbf{N}$ & $\%$ & \\
\hline Predominant material in the house & & & & & 0,282 \\
\hline Wood or similar materials & 301 & $85,5 \%$ & 72 & $80,9 \%$ & \\
\hline Cement or brick & 51 & $14,5 \%$ & 17 & $19,1 \%$ & \\
\hline Household floor material & & & & & 0,484 \\
\hline Wood or earth & 243 & $69,0 \%$ & 58 & $65,2 \%$ & \\
\hline Cement, brick, ceramic tile & 109 & $31,0 \%$ & 31 & $34,8 \%$ & \\
\hline Street Material & & & & & 0,704 \\
\hline Unpaved or earth & 258 & $73,3 \%$ & 67 & $75,3 \%$ & \\
\hline Brick or asphalt & 94 & $26,7 \%$ & 22 & $24,7 \%$ & \\
\hline Sidewalk & & & & & $<0,001$ \\
\hline No & 266 & $75,6 \%$ & 47 & $52,8 \%$ & \\
\hline Yes & 86 & $24,4 \%$ & 42 & $47,2 \%$ & \\
\hline Electricity in the household & & & & & 0,625 \\
\hline No & 12 & $3,4 \%$ & 4 & $4,5 \%$ & \\
\hline Yes* & 340 & $96,6 \%$ & 85 & $95,5 \%$ & \\
\hline Garbage collected by public service & & & & & 0,512 \\
\hline No & 28 & $8,0 \%$ & 9 & $10,1 \%$ & \\
\hline Yes & 324 & $92,0 \%$ & 80 & $89,9 \%$ & \\
\hline Open sewage & & & & & 0,005 \\
\hline No & 213 & $60,5 \%$ & 68 & $76,4 \%$ & \\
\hline Yes & 139 & $39,5 \%$ & 21 & $23,6 \%$ & \\
\hline Lavatory & & & & & $<0,001$ \\
\hline Sanitary with running water & 214 & $60,8 \%$ & 33 & $37,1 \%$ & \\
\hline Common grave or missing & 138 & $39,2 \%$ & 56 & $62,9 \%$ & \\
\hline Don't have running water systems & 111 & $31,5 \%$ & 29 & $32,6 \%$ & 0,849 \\
\hline Don't live in their own home & 107 & $30,4 \%$ & 45 & $50,6 \%$ & $<0,001$ \\
\hline Number of persons per household & & & & & 0,277 \\
\hline$\leq 4$ & 187 & $53,1 \%$ & 53 & $59,6 \%$ & \\
\hline$>4$ & 165 & $46,9 \%$ & 36 & $40,4 \%$ & \\
\hline Family income $\leq 1$ Salary in last 30 days & 132 & $40,5 \%$ & 13 & 15,1 & $<0,001$ \\
\hline Head of the family had not paid work in the last 90 days & 50 & $16,8 \%$ & 6 & $6,7 \%$ & 0,03 \\
\hline Receive a grant-aid $* *$ & 99 & $28,1 \%$ & 50 & $56,2 \%$ & $<0,001$ \\
\hline Education of the main caregiver & & & & & $<0,001$ \\
\hline$<8$ years & 182 & $51,7 \%$ & 26 & $29,5 \%$ & \\
\hline$\geq 8$ years & 170 & $48,3 \%$ & 62 & $70,5 \%$ & \\
\hline Transportation & & & & & $<0,001$ \\
\hline Walk or bike & 252 & $71,6 \%$ & 45 & $50,6 \%$ & \\
\hline Motorcycle & 54 & $15,3 \%$ & 36 & $40,4 \%$ & \\
\hline Car & 46 & $13,1 \%$ & 8 & $9,0 \%$ & \\
\hline Children with low height for age in the household & 52 & $15,5 \%$ & 8 & $9,1 \%$ & 0,124 \\
\hline
\end{tabular}

* In Iñapari, electrical power is supplied from the 06h 00h In Assis Brasil, through the "bolsa família" program (average of 70 reais per person).

** In Iñapari, distribution of milk through the "glass of milk". 
Sanitary conditions are more favorable in Assis Brasil, where there is a predominance of garbage collection by public and sanitary services. The households have running water systems. Nevertheless, open sewers are more frequently found in that city $(39.5 \%)$ than in Iñapari $(23.6 \%, p=0.005)$.

As regards economic characteristics, they seem to be more favorable Iñapari, where there is a predominance of family incomes that are higher than minimum wages and where heads of families more often have remunerated jobs. However, the number of families on social welfare and who do not own their own homes is also larger. The education of younger-than-five-year-old children's main care providers was better in Iñapari, as $70.5 \%$ of such carers reported to have attended school for 8 years or longer (AB: $48.3 \%, p<0.001$ ). The mean prevalence of height deficit for age in children was $12.3 \%$, and there were no significant statistical differences between the two cities (AB: $15.5 \%$; IN: 9.1\%, $p=0.124$ ).

The prevalence of food insecurity in the cities was similar (Table 2). Assis Brasil showed 40.6\% and Iñapari $38.2 \%(p=0.856)$. When it was stratified by type, Assis Brasil sho wed $24.1 \%$ of slight food insecurity and $16.5 \%$ of moderate and severe food insecurity.

Table 2: Brazilian Scale of Food insecurity and prevalence of food insecurity. Assis Brasil; Iñapari, 2011

\begin{tabular}{|c|c|c|c|c|c|}
\hline \multirow[b]{2}{*}{ Variables } & \multicolumn{2}{|c|}{$\begin{array}{l}\text { Assis Brasil } \\
\quad(n=352)\end{array}$} & \multicolumn{2}{|c|}{$\begin{array}{l}\text { Iñapari } \\
(n=89)\end{array}$} & \multirow[b]{2}{*}{ p-value } \\
\hline & $\mathbf{N}$ & $\%$ & $\mathbf{N}$ & $\%$ & \\
\hline \multicolumn{6}{|l|}{ Issues of the Brazilian Scale of Food Insecurity } \\
\hline 1. Concern that the food was over & 92 & $26,1 \%$ & 26 & $29,2 \%$ & 0,558 \\
\hline 2. The food is over & 62 & $17,6 \%$ & 19 & $21,3 \%$ & 0,416 \\
\hline 3. Ran out of money for a healthy and varied diet & 128 & $36,4 \%$ & 22 & $24,7 \%$ & 0,038 \\
\hline 4. Had to make do with only a few foods to feed a resident $<20$ years & 88 & $25,0 \%$ & 15 & $16,9 \%$ & 0,105 \\
\hline 5. Can not offer any resident $<20$ years a healthy and varied diet & 102 & $29,0 \%$ & 20 & $22,5 \%$ & 0,222 \\
\hline 6. A resident $<20$ years did not eat enough food & 39 & $11,1 \%$ & 10 & $11,2 \%$ & 0,967 \\
\hline 7. Some adult decreases the amount of food or did not do meals & 53 & $15,1 \%$ & 17 & $19,1 \%$ & 0,351 \\
\hline 8. Head of the family ate less because they had no money & 58 & $16,5 \%$ & 18 & $20,2 \%$ & 0,627 \\
\hline 9. Family head was hungry but did not eat because he had no money & 25 & $7,1 \%$ & 9 & $10,1 \%$ & 0,564 \\
\hline 10. Head of the family lost weight by not having money to buy food & 23 & $6,5 \%$ & 4 & $4,5 \%$ & 0,552 \\
\hline 11. An adult was a whole day without eating & 18 & $5,1 \%$ & 6 & $6,7 \%$ & 0,736 \\
\hline 12. Decreased the amount of food a resident $<20$ years & 39 & $11,1 \%$ & 12 & $13,5 \%$ & 0,769 \\
\hline 13. Head of the family failed to offer a meal to any resident $<20$ years & 24 & $6,8 \%$ & 7 & $7,9 \%$ & 0,832 \\
\hline 14. A resident $<20$ years was hungry but head of the family could not afford food & 23 & $6,5 \%$ & 6 & $6,7 \%$ & 0,879 \\
\hline 15. A resident $<20$ years was a whole day without eating & 4 & $1,1 \%$ & 3 & $3,4 \%$ & 0,284 \\
\hline Food Insecurity Level & & & & & 0,949 \\
\hline Food Safety & 209 & $59,4 \%$ & 55 & $61,8 \%$ & \\
\hline 'Mild' Insecurity & 85 & $24,1 \%$ & 19 & $21,3 \%$ & \\
\hline 'Moderate' Insecurity & 37 & $10,5 \%$ & 10 & $11,2 \%$ & \\
\hline 'Severe' Insecurity & 21 & $6,0 \%$ & 5 & $5,6 \%$ & \\
\hline
\end{tabular}

In Assis Brasil, socioeconomic and demographic characteristics varied according to the level of food security (Table 3 ). In the households showing severe and moderate food insecurity, unfavorable housing, sanitation and income conditions predominated, such as: wooden or earthen floors, unpaved streets without sidewalks, family income equal to or lower than minimum wages, among others. On the other hand, slightly more favorable conditions predominated in the households showing food security, such as brick houses with running waters systems and income equal to or higher than minimum wages. The households classified as being in mild insecurity showed similar physical housing conditions to those in moderate and severe insecurity, while sanitation conditions and income indicators showed to be intermediate between the households with food security and insecurity (Table 3).

In Iñapari, the households showed different physical characteristics according to the food security situation. Wooden houses with earthen floors were more frequent for households classified as being in food insecurity (Table 4).

The factors associated with food insecurity in the city of Assis Brasil, as obtained by multiple logistic regression, were wooden or earthen house floors, belonging to the poorest tercile and the number of household members (Table 5). Having a house with wooden or earthen floors increased the chances of being in food insecurity by 2.47 -fold as compared to having a house with cement, brick, ceramics or tile floors. Belonging to the poorest tercile increased the chance of food insecurity by 6.04 fold $(p<0.001)$, and the addition of each new dweller increased the chance of food insecurity in the household by $37 \%$.

\section{DISCUSSION}

The Brazil-Peru-Bolivia border region is formed by different nationalities, ethnicities and cultures that participate in the intense movements of people circulation in the region. The physical location poses similar challenges to both cities (Assis Brasil and Iñapari), while the cultural habits and economy of each country may be modifying factors of life conditions.

Socioeconomic and sanitation conditions in Assis Brasil and Iñapari show similarities and differences. The physical characteristics of the households are similar, con- 
Table 3: Socioeconomic characteristics, demographic and stunting according to (in) security food level. Assis Brasil, 2011

\begin{tabular}{|c|c|c|c|c|c|c|c|c|c|}
\hline \multirow[b]{2}{*}{ Variables } & \multicolumn{2}{|c|}{$\begin{array}{c}\text { Total } \\
(\mathrm{n}=352)\end{array}$} & \multicolumn{2}{|c|}{$\begin{array}{l}\text { Security Food } \\
\qquad(n=209)\end{array}$} & \multicolumn{2}{|c|}{$\begin{array}{l}\text { Mild Insecurity } \\
\qquad(\mathrm{n}=85)\end{array}$} & \multicolumn{2}{|c|}{$\begin{array}{l}\text { Moderate and Severe } \\
\qquad(n=58)\end{array}$} & \multirow[b]{2}{*}{$p$-value } \\
\hline & $\mathbf{N}$ & $\%$ & $\mathrm{~N}$ & $\%$ & $\mathrm{~N}$ & $\%$ & $\mathbf{N}$ & $\%$ & \\
\hline Predominant material in the house & & & & & & & & & 0,001 \\
\hline Wood or similar materials & 301 & $85,5 \%$ & 167 & $79,9 \%$ & 81 & $95,3 \%$ & 53 & $91,4 \%$ & \\
\hline Cement or brick & 51 & $14,5 \%$ & 42 & $20,1 \%$ & 4 & $4,7 \%$ & 5 & $8,6 \%$ & \\
\hline Household floor material & & & & & & & & & $<0,001$ \\
\hline Wood or earth & 109 & $69,0 \%$ & 123 & $58,9 \%$ & 68 & $80,0 \%$ & 52 & $89,7 \%$ & \\
\hline Cement, brick, ceramic tile & 243 & $31,0 \%$ & 86 & $41,1 \%$ & 17 & $20,0 \%$ & 6 & $10,3 \%$ & \\
\hline Street Material & & & & & & & & & $<0,001$ \\
\hline Unpaved or earth & 258 & $73,3 \%$ & 138 & $66,0 \%$ & 68 & $80,0 \%$ & 52 & $89,7 \%$ & \\
\hline Brick or asphalt & 94 & $26,7 \%$ & 71 & $34,0 \%$ & 17 & $20,0 \%$ & 6 & $10,3 \%$ & \\
\hline Sidewalk & 86 & $24,4 \%$ & 67 & $32,1 \%$ & 13 & $15,3 \%$ & 6 & $10,3 \%$ & $<0,001$ \\
\hline Lavatory & & & & & & & & & $<0,001$ \\
\hline Sanitary with running water & 214 & $60,8 \%$ & 152 & $72,7 \%$ & 43 & $50,6 \%$ & 19 & $32,8 \%$ & \\
\hline Common grave or missing & 138 & $39,2 \%$ & 57 & $27,3 \%$ & 42 & $49,4 \%$ & 39 & $67,2 \%$ & \\
\hline Don't have running water systems & 111 & $31,5 \%$ & 41 & $19,6 \%$ & 36 & $42,4 \%$ & 34 & $58,6 \%$ & $<0,001$ \\
\hline Don't live in their own home & 107 & $30,4 \%$ & 54 & $25,8 \%$ & 25 & $29,4 \%$ & 28 & $48,3 \%$ & 0,004 \\
\hline$>4$ residents per household & 165 & $46,9 \%$ & 82 & $39,2 \%$ & 46 & $54,1 \%$ & 37 & $63,8 \%$ & 0,002 \\
\hline $\begin{array}{l}\text { Family income } \leq 1 \text { Salary in last } 30 \text { days } \\
\text { Head of the family had not paid work in the last } 90 \text { days }\end{array}$ & 132 & $40,5 \%$ & 52 & $26,9 \%$ & 45 & $55,6 \%$ & 35 & $67,3 \%$ & $\begin{array}{c}<0,001 \\
0,042\end{array}$ \\
\hline & & & 29 & $15,3 \%$ & 8 & $12,3 \%$ & 13 & $29,5 \%$ & \\
\hline Receive a grant-aid* & 99 & $28,1 \%$ & 32 & $15,3 \%$ & 34 & $40,0 \%$ & 33 & $56,9 \%$ & $<0,001$ \\
\hline Socioeconomic index & & & & & & & & & $<0,001$ \\
\hline Tertile richest & 128 & - & 101 & $48,8 \%$ & 21 & $24,7 \%$ & 6 & $10,3 \%$ & \\
\hline 2nd tertile & 131 & - & 77 & $37,2 \%$ & 32 & $37,6 \%$ & 22 & $37,9 \%$ & \\
\hline Tertile poorest & 91 & - & 29 & $14,0 \%$ & 32 & $37,6 \%$ & 30 & $51,7 \%$ & \\
\hline Education of the main caregiver & & & & & & & & & $<0,001$ \\
\hline$<8$ years & 182 & $51,7 \%$ & 81 & $38,8 \%$ & 55 & $64,7 \%$ & 46 & $79,3 \%$ & \\
\hline$\geq 8$ years & 170 & $48,3 \%$ & 128 & $61,2 \%$ & 30 & $35,3 \%$ & 12 & $20,7 \%$ & \\
\hline Car or bike for transportation & 252 & $71,5 \%$ & 79 & $37,8 \%$ & 18 & $21,2 \%$ & 3 & $5,2 \%$ & $<0,001$ \\
\hline Children with low height for age in the household & 52 & $15,50 \%$ & 22 & $10,9 \%$ & 18 & $22,5 \%$ & 12 & $22,2 \%$ & 0,018 \\
\hline
\end{tabular}

* Grant-aid through the "bolsa família" program (average of 70 reais per person).

Table 4: Socioeconomic characteristics, demographic and stunting according to (in) security food level. Iñapari, 2011

\begin{tabular}{|c|c|c|c|c|c|c|c|}
\hline \multirow[b]{2}{*}{ Variables } & \multicolumn{2}{|c|}{$\begin{array}{c}\text { Total } \\
(\mathrm{n}=89)\end{array}$} & \multicolumn{2}{|c|}{$\begin{array}{l}\text { Security Food } \\
\qquad(n=55)\end{array}$} & \multicolumn{2}{|c|}{$\begin{array}{l}\text { Insecurity Food } \\
\qquad(\mathrm{n}=85)\end{array}$} & \multirow[b]{2}{*}{ p-value } \\
\hline & $\mathbf{N}$ & $\%$ & $\mathbf{N}$ & $\%$ & $\mathbf{N}$ & $\%$ & \\
\hline Predominant material in the house & & & & & & & 0,013 \\
\hline Wood or similar materials & 72 & $80,9 \%$ & 40 & $72,7 \%$ & 32 & $94,1 \%$ & \\
\hline Cement or brick & 51 & $14,5 \%$ & 42 & $20,1 \%$ & 4 & $4,7 \%$ & \\
\hline Household floor material & & & & & & & $<0,001$ \\
\hline Wood or earth & 31 & $65,2 \%$ & 26 & $47,3 \%$ & 32 & $94,1 \%$ & \\
\hline Cement, brick, ceramic tile & 58 & $34,8 \%$ & 29 & $52,7 \%$ & 2 & $5,9 \%$ & \\
\hline Street Material & & & & & & & 0,838 \\
\hline Unpaved or earth & 67 & $75,3 \%$ & 41 & $74,5 \%$ & 26 & $76,5 \%$ & \\
\hline Brick or asphalt & 22 & $24,7 \%$ & 14 & $25,5 \%$ & 8 & $23,5 \%$ & \\
\hline Sidewalk & 42 & $47,2 \%$ & 26 & $47,3 \%$ & 16 & $47,1 \%$ & \\
\hline Lavatory & & & & & & & 0,468 \\
\hline Sanitary with running water & 33 & $37,1 \%$ & 22 & $40,0 \%$ & 11 & $32,4 \%$ & \\
\hline Common grave or missing & 56 & $62,9 \%$ & 33 & $60,0 \%$ & 23 & $67,6 \%$ & \\
\hline Don't have running water systems & 29 & $32,6 \%$ & 14 & $25,5 \%$ & 15 & $44,1 \%$ & 0,068 \\
\hline Don't live in their own home & 45 & $50,6 \%$ & 27 & $49,1 \%$ & 18 & $52,9 \%$ & \\
\hline$>4$ residents per household & 36 & $40,4 \%$ & 24 & $43,6 \%$ & 12 & $35,3 \%$ & 0,436 \\
\hline Family income $\leq 1$ Salary in last 30 days & 13 & $15,1 \%$ & 7 & $13,2 \%$ & 6 & $18,2 \%$ & 0,55 \\
\hline Head of the family had not paid work in the last 90 days & 6 & $6,7 \%$ & 2 & $3,9 \%$ & 4 & $12,5 \%$ & 0,199 \\
\hline $\begin{array}{l}\text { Receive a grant-aid } \\
\text { Socioeconomic index }\end{array}$ & 50 & $56,2 \%$ & 27 & $49,1 \%$ & 23 & $67,6 \%$ & $\begin{array}{l}0,086 \\
0,188\end{array}$ \\
\hline & 29 & - & 20 & $36,4 \%$ & 9 & $26,5 \%$ & \\
\hline Tertile richest & 29 & - & 20 & $36,4 \%$ & 9 & $26,5 \%$ & \\
\hline $2^{\text {nd }}$ tertile & 31 & - & 21 & $38,2 \%$ & 10 & $29,4 \%$ & \\
\hline Tertile poorest & 29 & - & 14 & $25,5 \%$ & 15 & $44,1 \%$ & \\
\hline Education of the main caregiver & & & & & & & 0,983 \\
\hline$<8$ years & 26 & $29,5 \%$ & 16 & $29,6 \%$ & 10 & $29,4 \%$ & \\
\hline$\geq 8$ years & 62 & $70,5 \%$ & 38 & $70,4 \%$ & 24 & $70,6 \%$ & \\
\hline Car or bike for transportation & 44 & $49,4 \%$ & 28 & $50,9 \%$ & 16 & $47,1 \%$ & 0,724 \\
\hline Children with low height for age in the household & 8 & $9,1 \%$ & 6 & $10,9 \%$ & 2 & $6,1 \%$ & $0,705^{*}$ \\
\hline
\end{tabular}


Table 5: Factors associated with food insecurity obtained by multiple logistic regression. Assis Brazil

\begin{tabular}{lccccc} 
Variables & OR crude & (Cl 95\%) & OR adjust & (Cl 95\%) & p-value \\
$\begin{array}{l}\text { Household floor material } \\
\quad \text { Cement, brick, ceramic tile }\end{array}$ & 1 & 1 & & & \\
$\quad$ Wood or earth & 3,64 & $(2,15-6,15)$ & 2,47 & $(1,38-4,41)$ & 0,002 \\
$\quad \begin{array}{l}\text { Socioeconomic index } \\
\quad \text { Tertile richest }\end{array}$ & 1 & 1 & 1 & 1 & \\
$\quad$ 2nd tertile & 2,32 & $(1,36-3,99)$ & 1,73 & $(0,96-3,11)$ & 0,07 \\
$\quad$ Tertile poorest & 7,45 & $(4,12-13,46)$ & 6,04 & $(3,2-11,41)$ & $<0,001$ \\
$\quad$ Number of household members (continuous var.) & 1,34 & $(1,17-1,52)$ & 1,37 & $(1,18-1,59)$ & $<0,001$ \\
\hline
\end{tabular}

sidering that they are located in the Amazon region, and the availability and cost of construction materials are similar. The number of households with electric power supply and public garbage collection is also similar, thus showing that the Amazon region has already managed to create the necessary conditions for public services and electric power distribution in its realms, although, in Iñapari electric power is supplied only during part of the day; income and sanitation conditions, one the other hand, are very different in the two cities. Family income, employment rates, maternal education and sanitation conditions provided by public authorities (more sidewalks and fewer open sewers) are better in Iñapari, but individual sanitation conditions are improved in Assis Brasil (more houses with toilets with running water). On the other hand, the number of households with running water inside is similar. Considering these results, we can state that some socioenvironmental characteristics are due to the geographic location (a remote region of the Amazon), while others probably result from the very cultural conditions of each country (for instance, a larger number of cesspools in the city where family income is higher).

Studies on other border areas with these characteristics, such as the Argentina-Brazil-Paraguay Triple Frontier, have pointed out various social and health problems that are common to the three border countries, such as the binomial malnutrition/overweight, child sexual exploitation, drug trafficking and respiratory diseases ${ }^{26,27}$. Food security is related to the estimation of food availability, in terms of quantity and quality. The Amazon region has peculiarities as regards the supply of food and its variability. Beef and lamb production entails deforestation; game meat, although abundant, cannot be consumed. The Amazon soil and climate are improper for various cultures, which causes the demand for foodstuffs importation to be large. On the other hand the logistics for nonperishable food distribution is complex and results in high cost to consumers while perishable food is difficult to distribute before it becomes improper for consumption. Even the supply of regional edible fruit is heterogeneous within the Amazon, and such difficulties can equally affect both cities due to their geographic location. However, food from the Andes, such as grapes, plums and tuna as well as tubers and grains can reach Iñapari, but, although it would favor a larger variability of foodstuffs, the same does not happen in Assis Brasil due to international restrictions. Despite this fact, the prevalence of food insecurity found in this study be- tween Assis Brasil and Iñapari was similar, thus showing that both border cities are susceptible to the same determinant factors for food insecurity. Therefore, it is a problem that is common to the two countries.

The prevalence of food insecurity found by our study in Assis Brasil is lower than the average in Acre state (47.5\%); however, it must be taken into account that PNAD joins results from urban and rural areas, in addition to gathering data from the capital with data from isolated cities from inner Acre state, the access to which is only by inland waterways or air. In these remote areas of the state are cities with the highest prevalence of malnutrition in Brazil ${ }^{28}$, which is probably the reason why the mean prevalence of food insecurity in Acre is larger than that in the Northern Region as well as than the national average. Additionally, our study involves only families that have children under 5 years of age while PNAD samples all households.

There are few data available concerning estimates of food insecurity in the Amazon region. A study on 194 families from the urban area of Manaus estimated that the prevalence of food insecurity affected $89.1 \%$ of families ${ }^{15}$. In the Legal Amazon in Mato Grosso state - Brazil, a study on households with adolescents in the urban area estimated the prevalence of moderate and severe food insecurity as $23,1 \%{ }^{16}$.

The estimates by PNAD for the Northern and Northeaster Regions were 3.1 and 3.5-fold higher than that for the Southern Region ${ }^{29}$. In agreement with that report, a recent study conducted in Pelotas (RS) estimated the prevalence of food insecurity as $11 \%{ }^{30}$.

In Peru, there is only one published study on food security to this date. Vargas and Penny ${ }^{31}$ estimated the prevalence of food insecurity in three regions in Peru (the seacoast, Andes and Amazon regions) in 2002. The San Martin Region (Peruvian Amazon) showed the highest prevalence (56\%), and the Andes Region showed the lowest prevalence of food insecurity $(51 \%)$. Although the collection instrument was different from that used in our study, the prevalence of food insecurity in Iñapari was lower than that found by Vargas and Penny ${ }^{31}$. A real decrease in food insecurity may have occurred in the Peruvian Amazon between 2002 and 2011, considering that the same occurred in the Brazilian Amazon $58.9 \%$ of food insecurity in Acre by the 2004 PNAD to $47.5 \%$ by the 2009 PNAD $)^{4}$. Another explanation for the difference found is due to the fact that our study included only families from the urban area that had children under 5 years of age. 
The main causes for food insecurity in Iñapari and Assis Brasil refer to unfavorable socioeconomic conditions (low income, large number of dwellers and households that are not made of bricks). These data are confirmed by other studies ${ }^{30,32,33}$ that also identified an association of a large number of dwellers in the household(32), houses made of $\operatorname{wood}^{30}$ and low family income ${ }^{34,35}$ with higher food insecurity prevalence. In addition to these variables, deficient basic sanitation ${ }^{33,36}$ and the poor education of the reference person in the family ${ }^{32,36}$ were also more frequent in families living in food insecurity.

In this investigation, almost half of the families in Assis Brasil reported a monthly income that was lower than or equal to minimum wages. According to the Family Budget Survey (Pesquisa de Orçamento Familiar - POF 2008-2009) ${ }^{37}$ total income is one of the main determinants in the construction of the family budget: the lowest the family's monthly income, the largest the proportion of households in a situation of moderate or severe food insecurity ${ }^{4}$.

\section{CONCLUSION}

This study shows that, in the Amazon Region, income is still the main factor associated with food insecurity. Considering that the food available in the Amazon retail shops is more expensive than in the other regions in Brazil, it is important that studies on the edible potential of regional fruit and fish and new technologies for using them be performed in order to promote food security.

\section{CONTRIBUTIONS}

AAR, NAV, CHMLE and MdaSN conceived the study and developed the study protocol; TMP, FLCCB, HOG, BMD, AMB, ACM, JAFJ, APS, RGC, ASG, TSA, CSMO, MdaSN, AAR, NAV and CHMLE participated in the process for selecting the research instrument and the sampling strategy, in addition to performing data collection; SASM, AAR, and MdaSN analyzed and interpreted the data. AAR and MdaSN wrote the manuscript. All the other authors participated in the critical review of the manuscript and contributed to the discussion of results and to the review of the intellectual content in the research. A81 the authors read and approved the final version of the manuscript.

\section{REFERENCES}

1. Brasil. Ministério da Saúde. Secretaria de Atenção à Saúde. Guia alimentar para a população brasileira: promovendo a alimentação saudável. Brasília: Ministério da Saúde; 2008.

2. United Nations (UN). The millennium development goals report 2010. [cited 2016 Sep 26] Available from: http://www.bvsde.paho.org/texcom/cd045364/MDGreport2010.pdf

3. Organización de las Naciones Unidas para la Alimentación y la Agricultura. El estado de la inseguridad alimentaria en el mundo: ¿cómo afecta la volatilidad de los precios internacionales a las economías nacionales y la seguridad alimentaria? Rome: $2011 ;$ p.56.

4. Instituto Brasileiro de Geografia e Estatística (IBGE). Pesquisa Nacional por Amosta de Domicílios: Segurança alimentar: 2004/2009. [cited 2016 Sep 26] Available from: http://pesquisa.bvsalud.org/portal/resource/pt/lil-593492

5. Panigassi G, Segall-Corrêa AM, Marin-León L, Pérez-Escamilla R, Sampaio MFA, Maranha LK. Insegurança alimentar como indicador de iniqüidade: análise de inquérito populacional. Cad Saude Publica. 2008;24(10):2376-84. DOI: http://dx.doi.org/10.1590/S0102-311X2008001000018

6. Habicht JP, Pelto G, Frongillo E, Rose D. Conceptualization and instrumentation of food insecurity. 2004. [cited 2016 Sep 26] Available from: http://www7.national-academies.org/cnstat/Conceptualization_and_Instrumentation_of_Food_Security_Paper.pdf

7. Campbell CC. Food insecurity: a nutritional outcome or a predictor variable? J Nutr. 1991;121(3):408-15.

8. Maia RRP, Souza JMP. Fatores associados ao baixo peso ao nascer em municipio do Norte do Brasil. J Hum Growth Dev. 2010;20(3):735-44. DOI: http://dx.doi.org/10.7322/jhgd.19981

9. Souza OF, Farias ES. Magreza e sobrepeso em escolares de Rio Branco, AC, Brasil. J Hum Growth Dev. 2011;21(3):878-82. DOI: http://dx.doi.org/10.7322/jhgd.20040

10. Rose D, Bodor JN. Household food insecurity and overweight status in young school children: results from the Early Childhood Longitudinal Study. Pediatrics. 2006;117(2):464-73. DOI: http://dx.doi.org/10.1542/ peds.2005-0582

11. Gundersen C, Garasky S, Lohman BJ. Food insecurity is not associated with childhood obesity as assessed using multiple measures of obesity. J Nutr. 2009;139(6):1173-8. DOI: http://dx.doi.org/10.3945/ jn.109.105361

12. Ortiz-Hernández L, Acosta-Gutiérrez MN, Núñez-Pérez AE, Peralta-Fonseca N, Ruiz-Gómez Y. En escolares de la Ciudad de México la inseguridad alimentaria se asoció positivamente con el sobrepeso. Rev Invest Clin. 2007;59(1):32-41.

13. Hackett $M$, Melgar-Quiñonez $H$, Alvarez MC. Household food insecurity associated with stunting and underweight among preschool children in Antioquia, Colombia. Rev Panam Salud Publica. 2009; 25(6): 506-10.

14. Carvalho AT, Almeida ER, Nilson EAF, Ubarana JA, Coutinho JG, Vianna RPT, et al. Situação nutricional de crianças menores de cinco anos em municipios do Nordeste Brasileiro. J Hum Growth Dev. 2014;24(2):221-7. DOI: http://dx.doi.org/10.7322/jhgd.81275 
15. Yuyama LKO, Aguiar JPL, Pantoja L, Maeda RN, Melo T, Alencar FH, et al. Segurança/insegurança alimentar em famílias urbanas e rurais no estado do Amazonas: I. validação de metodologia e de instrumento de coleta de informação. Acta Amaz. 2007;37(2):247-52. DOI: http://dx.doi.org/10.1590/S004459672007000200011

16. Guerra LDS, Espinosa MM, Bezerra ACD, Guimarães LV, Lima-Lopes MA. Insegurança alimentar em domicílios com adolescentes da Amazônia Legal Brasileira: prevalência e fatores associados. Cad Saude Publica. 2013;29(2):335-48. DOI: http://dx.doi.org/10.1590/S0102-311X2013000200020

17. Alencar FH, Yuyama LKO, Varejão M de JC, Marinho HA. Determinantes e conseqüências da insegurança alimentar no Amazonas: a influência dos ecossistemas. Acta Amaz. 2007;37(3):413-8.

18. Instituto Brasileiro de Geografia e Estatística (IBGE). Resultados do Censo 2010: Estado do Acre. [cited 2014 Oct 08]. Available from: http://www.ibge.gov.br/home/estatistica/populacao/censo2010/tabelas_pdf/ total_populacao_acre.pdf

19. Instituto Nacional de Estadística y Informatica (INEI). Censos Nacionales 2007, XI de Población y VI de Vivienda. [cited 2014 May 03]. Available from: http://proyectos.inei.gob.pe/Censos2007/

20. Instituto de Urbanismo y Planificación del Perú. Plan de desarrollo urbano de La ciudade de Iñapari. [cited 2014 May 10]. Available from: http://bvpad.indeci.gob.pe/doc/estudios_CS/Region_Madre_de_Dios/ tahuamanu/inapari_pdull.pdf

21. Filmer D, Pritchett LH. Estimating Wealth Effects without Expenditure Data-or Tears: An Application to Educational Enrollments in States of India. Demography. 2001;38(1):115-32.

22. Ramalho AA, Mantovani SA, Delfino BM, Pereira TM, Martins AC, Oliart-Guzmán $H$, et al. Nutritional status of children under 5 years of age in the Brazilian Western Amazon before and after the Interoceanic highway paving: a population-based study. BMC Public Health. 2013;13:1098. DOI: http://dx.doi.org/10.1186/14712458-13-1098

23. Segall-Corrêa AM, Marín-León L, Pérez-Escamilla R. Escala Brasileira de Medida da Insegurança Alimentar (EBIA): validação, usos e importância para as políticas públicas. In: Aranha AV. Fome Zero: uma historia brasileira. v. 3. Brasília: Ministério do Desenvolvimento Social e Combate à Fome; 2010; p.26-43.

24. Escala Latinoamericana y Caribena de seguridad alimentaria (ELCSA). Manual de uso y aplicaciones. [cited 2014 Dec 17]. Available from: http://www.foodsec.org/fileadmin/user_upload/eufao-fsi4dm/docs/elcsa. pdf

25. World Health Organization (WHO). Physical status: the use and interpretation of anthropometry. Geneva: World Health Organization; 1995.

26. Fundo das Nações Unidas para a Infância (UNICEF). Itaipu Binacional. Oficina Regional do Unicef para América Latina e Caribe (TACRO). Situação das crianças e dos adolescentes na tríplice fronteira entre Argentina, Brasil e Paraguai: desafios e recomendações. Itaipu Binacional; 2005.

27. Legnani E, Legnani RFS, Barbosa Filho VC, Krinski K, Elsangedy HM, Campos W, et al. Fatores associados ao excesso de peso corporal em escolares da tríplice fronteira: Argentina, Brasil e Paraguai. ALAN. 2010;60(4):340-7.

28. Benício MHD, Martins APB, Venancio SI, Barros AJD. Estimates of the prevalence of child malnutrition in Brazilian municipalities in 2006. Rev Saúde Pública. 2013;47(3):1-10. DOI: http://dx.doi.org/10.1590/ S0034-8910.2013047004379

29. Instituto Brasileiro de Geografia e Estatística (IBGE). Pesquisa Nacional por Amosta de Domicílios: Segurança alimentar: 2004. Rio de Janeiro; 2006.

30. Santos JV, Gigante DP, Domingues MR. Prevalência de insegurança alimentar em Pelotas, Rio Grande do Sul, Brasil, e estado nutricional de indivíduos que vivem nessa condição. Cad Saúde Pública. 2010;26(1):41-9. DOI: http://dx.doi.org/10.1590/S0102-311X2010000100005

31. Vargas S, Penny ME. Measuring food insecurity and hunger in Peru: a qualitative and quantitative analysis of an adapted version of the USDA's Food Insecurity and Hunger Module. Public Health Nutr. 2010;13(10):1488-97. DOI: http://dx.doi.org/10.1017/S136898000999214X

32. Salles-Costa R, Pereira RA, Vasconcellos MTL, Veiga GV, Marins VMR, Jardim BC, et al. Associação entre fatores socioeconômicos e insegurança alimentar: estudo de base populacional na Região Metropolitana do Rio de Janeiro, Brasil. Rev Nutr. 2008;21(Supl.0):99s-109s.

33. Peixoto MRG, Ramos K, Martins KA, Schincaglia RM, Braudes-Silva LA. Insegurança alimentar na área de abrangência do Núcleo de Apoio à Saúde da Família em Itumbiara, Goiás. Epidemiol Serv Saúde. 2014;23(2):327-36. DOI: http://dx.doi.org/10.5123/S1679-49742014000200014

34. Vianna RPT, Segall-Corrêa AM. Insegurança alimentar das famílias residentes em municípios do interior do estado da Paraíba, Brasil. Rev Nutr. 2008;21(Supl.0):111s-122s.

35. Fávaro T, Ribas DLB, Zorzatto JR, Segall-Corrêa AM, Panigassi G. Segurança alimentar em famílias indígenas Teréna, Mato Grosso do Sul, Brasil. Cad Saúde Pública. 2007;23(4):785-93. DOI: http://dx.doi. org/10.1590/S0102-311X2007000400006

36. Hoffmann R. Determinantes da Insegurança Alimentar no Brasil: Análise dos Dados da PNAD de 2004. Segurança Alimentar Nutr. 2008;15(1):49-61. DOI: http://dx.doi.org/10.20396/san.v15i1.1824 
37. Instituto Brasileiro de Geografia e Estatística (IBGE). Pesquisa de orçamentos familiares 2008-2009: antropometria e estado nutricional de crianças, adolescentes e adultos no Brasil. Rio de Janeiro: IBGE; 2010.

This article is distributed under the terms of the Creative Commons Attribution 4.0 International License (http://creativecommons.org/licenses/by/4.0/), which permits unrestricted use, distribution, and reproduction in any medium, provided you give appropriate credit to the original author(s) and the source, provide a link to the Creative Commons license, and indicate if changes were made. The Creative Commons Public Domain Dedication waiver (http://creativecommons.org/publicdomain/zero/1.0/) applies to the data made available in this article, unless otherwise stated.

\section{Resumo:}

A segurança alimentar e nutricional consiste na realização do direito de todos ao acesso regular e permanente a alimentos de qualidade, em quantidade suficiente, sem comprometer o acesso a outras necessidades essenciais, tendo como base práticas alimentares promotoras de saúde que respeitem a diversidade cultural e que sejam ambiental, cultural, econômica e socialmente sustentáveis. O objetivo deste estudo foi estimar a prevalência e os fatores associados a insegurança alimentar em famílias com crianças menores de cinco anos na fronteira amazônica Brasil - Peru. O estudo foi realizado nos municípios de Assis Brasil (Brasil) e Iñapari (Peru) localizados na tríplice fronteira formada por Brasil, Bolívia e Peru. Dos 441 domicílios com crianças menores de 5 anos identificados, 352 (79,82\%) localizavam-se em Assis Brasil, e os demais em Iñapari. As prevalências de insegurança alimentar nos municípios são semelhantes. Assis Brasil apresentou 40,6\% e Iñapari 38,2\% ( $p=0,856)$. Em Assis Brasil, ter domicilio com piso de madeira ou terra aumentou em 2,47 vezes a chance de insegurança alimentar comparado a piso de cimento, tijolo, cerâmica ou lajota. Pertencer ao tercil mais pobre aumentou a chance da insegurança alimentar em 6,04 vezes $(p<0,001)$, e o incremento de cada novo morador aumentou $37 \%$ a chance de insegurança alimentar no domicílio. Este estudo mostra que na região amazônica a renda ainda é o principal fator associado a insegurança alimentar.

Palavras-chave: segurança alimentar e nutricional, saúde na fronteira, fome. 